\title{
DEFENSIVE ACID-SECRETION IN MARINE GASTROPODS
}

\author{
By T. E. THOMPSON \\ Marine Biological Station, Port Erin, Isle of Man*
}

(Text-fig. I)

An important function of the gastropod shell is to protect the body against attack by predators. If the shell of a whelk is broken away and the soft animal is then offered to a hungry cod, it is eaten readily. Many successful gastropods, however, lack an external shell as adults (although it is certain that all have evolved from shelled ancestors) and might be expected to be eaten by fish as readily as is the naked body of a broken whelk. The purpose of this paper is to describe part of an investigation into whether this is in fact true.

Some authors have considered that many of these naked gastropods (the majority of which belong to the Opisthobranchia) escape being eaten by their cryptic coloration and their habit of 'skulking under stones or in crannies' (Crossland, I9II, p. 1063). Some have considered that many opisthobranchs are distasteful in various ways and believed the behaviour and coloration of such forms to be 'warning' in nature. Thus it might be expected that, under experimental conditions, cryptically coloured opisthobranchs would be accepted as food by fish while the more vividly coloured ones would be rejected, for the usual line of reasoning indicates that aposematic or warning coloration and behaviour accompany the possession of some defensive mechanism, while cryptic coloration and habits usually characterize animals which would be quickly killed and eaten if plainly visible to their enemies. Few experiments have been done with opisthobranchs. Herdman \& Clubb (1892) describe some interesting experiments with marine aquarium fish and nudibranchs, but these were inconclusive since only a very few species of the latter were used. Crossland (I9II) established that fish refused live chromodorid nudibranchs thrown to them from a boat in shallow water, while readily accepting other food and even taking formalin-soaked oysters. Many workers tended to be over-subjective and were handicapped by disagreements, often resulting from the description of animals removed from their natural surroundings. For instance, Crossland (I9II, p. I064) states that 'Tritonids ... are fairly conspicuously coloured', while most other authorities would agree that tritoniids resemble closely the alcyonarians on which they live and feed. Similarly, Cooke (I895, p. 73) states that Pleurobranchus membranaceus

\footnotetext{
* Present address: Zoology Department, University College, Cardiff.
} 
is "conspicuously marked with red-brown and yellowish "warning" colours. Haminoea and Philine, on the other hand, are good to eat, and consequently possess "protective" coloration'; these statements are based on faulty knowledge of these opisthobranchs.

It is clear that a full re-examination of the subject is necessary. To this end, I have made observations on as wide a variety of naked gastropods as possible, attempting to relate the results obtained to the facts of their natural history and anatomical and histological structure. The present paper describes the results of a part of this work, dealing with some gastropods which proved to rely on the production of an acid fluid for the deterrence of would-be predators. That Pleurobranchus membranaceus was able to secrete an acid substance has been known for many years (Garstang, 1890). Other species of gastropods now found to do this are: Berthella plumula (Opisthobranchia:Pleurobranchidae); Philine quadripartita (Opisthobranchia:Philinidae); Lamellaria perspicua (Prosobranchia:Lamellariidae); Velutina velutina (Prosobranchia: Lamellariidae). Velutina is not truly naked but observations on it are included here for it raises some interesting points. Some observations on Pleurobranchus are given by Thompson \& Slinn (1959).

The classification and nomenclature employed herein are those advocated by the Port Erin Fauna list (to be published).

\section{METHODS}

In the feeding-acceptability tests the fish used were in glass-fronted tanks in the Port Erin Aquarium, illuminated artificially, and usually fed twice per week with chopped herring or boiled mussels. Experiments were always carried out when the fish were to be expected to be hungry and this was confirmed by giving them some of their usual food before and after the experiments. The gastropod to be tested was dropped into the tank from above and allowed to sink to the bottom; the responses of the various fish were noted. Particular care was taken to ensure that the gastropods to be used in the tests were not damaged or in any way feeble, for previous experience had shown that, when vitality is low, resistance to predators may fall. It is admitted that the results of such tests must be interpreted with caution for a variety of reasons; the reliability of the results obtained will be discussed below.

Material for sectioning was fixed in Zenker's fluid (with or without acetic acid) or Lewitsky's fluid with sodium chloride added, cleared with amyl acetate and embedded in Hance's rubber wax (Gurr). Sections were cut at 4 and $6 \mu$. The stains employed were either the azan or the alum haematoxylin of Heidenhain, with, as counterstains for the latter, eosin and alcian blue $8 \mathrm{GS}$ (Steedman, 1950). In addition, preparations stained intravitally with neutral red were useful. 


\section{Tests with fish \\ RESULTS OF ACCEPTABILITY TESTS}

Some tests carried out using Pleurobranchus membranaceus have been described by Thompson \& Slinn (1959). In the present investigation further experiments with this species have yielded confirmatory data.

With Philine quadripartita, Lamellaria perspicua and Berthella plumula, essentially similar results were obtained in the present study. No tests were carried out using Velutina velutina, for only one live specimen was available and this was required for study of the histology of the foot.

Fish used in the tests were Blennius pholis, Acanthocottus bubalis, Pholis gunnellus, Pleuronectes platessa, Spinachia spinachia, Gadus morrhua, Pollachius pollachius and P. virens. (Tests with Agonus cataphractus and Ciliata mustelas were unsatisfactory for these fish invariably ignored test organisms.) The usual reaction to the test animal was for the fish to inspect it closely; the height in the tank at which the fish became aware of the mollusc and the means of inspection (olfactory or optical) varied with the different species of fish. Occasionally a fish would take one of the test molluscs into its mouth, but invariably rejected it violently and immediately. In a tank containing several pollack (Pollachius pollachius) a single test mollusc may be inspected, taken into the mouth and rejected by every fish present before it reaches the tank bottom. No evidence that any of the fish 'learned' to ignore these molluscs was obtained. There is little point in describing in detail the reactions of the various species of fish employed, for the behaviour of fish with regard to test foods has been described particularly fully by Bateson (I890).

To summarize: none of the four species of gastropod used was ever seen to be ingested by any of the fish employed; occasionally the fish would 'taste' the mollusc but always rejected it. The following observations are relevant to the contention that the tests yielded reliable data, and reflect the probable behaviour of these fish when encountering these molluscs in nature: $(a)$ in nature, large numbers of swimming Pleurobranchus were ignored by shoals of coalfish ( $P$. virens) (Thompson \& Slinn, I959); (b) a detailed study of the gut contents of gadoid fish from the seas around the south of the Isle of Man (personal communication from A. K. Nagabhushanam) revealed none of the molluscs under consideration, except for a specimen of Velutina velutina from the stomach of a coalfish, $P$. virens, in December 1956).

\section{Tests with anemones}

Thompson \& Slinn (I959) state that Tealia felina rejected live Pleurobranchus in laboratory tests. This has been confirmed and found to apply also to Berthella plumula, but with this important proviso: rejection only occurs predictably the first time the test is performed with any individual gastropod; if a rejected pleurobranchid is immediately placed in the tentacles of a fresh 
Tealia, the mollusc is often ingested readily. The significance of this is difficult to estimate; escape from the first anemone may have temporarily exhausted the deterrent reserves of the pleurobranchid.

\section{ACID SECRETION}

If the molluscs under consideration are roughly stimulated with a glass rod and a $\mathrm{pH}$ paper is applied, it can be seen that a strongly acid secretion has been produced. The $\mathrm{pH}$ estimations were made with B.D.H. wide-range papers; the colour change indicated the acidity of the secretion to be approximately $\mathrm{pH}$. The secretion is not produced continuously but only after a disturbance; $\mathrm{pH}$ papers resting lightly upon the animal while it is creeping exhibit no colour change.

Thompson \& Slinn (I959) found that the nature of this acid secretion in Pleurobranchus was relatively simple; it may be considered to be a mixture of sulphuric and hydrochloric acids, the former predominating. No organic acid radicals were identified nor were proteins present in appreciable amounts. The proportion of sulphate to chloride was much higher in the secretion than in either sea water or molluscan blood (Robertson, 1949).

In Pleurobranchus, Berthella, Philine and Lamellaria the acid secretion was produced at any point on the body surface; even the gills of the two pleurobranchid species are able to secrete this acid if disturbed. In Velutina the foot certainly was able to produce acid, but it is not certain whether in addition the mantle has this capacity.

\section{ACID-SECRETING TISSUES}

Pleurobranchus membranaceus

Thompson \& Slinn (1959) describe the histology of the mantle and foot epidermis. The 'empty' appearance of the epidermal cells is characteristic of acid-secreting tissues in the gastropods investigated. Scattered unicellular mucus glands are also present, especially in the pedal epidermis.

Sections through the gill show epidermal acid cells to be abundant. The metapodial gland (which develops as maturity is reached) has a totally different structure, packed with large compound multicellular glands of complex cytological aspect; its functions are presumably connected with adhesion to the substratum.

In sections through the mantle, cilia are never detectable (although plainly evident in life) but they are clearly demonstrable in sections through the foot.

Berthella plumula

The epidermis of Berthella shows only minor differences from that of Pleurobranchus. The contents of the acid cells in life stain red with neutral 
red; it is well known that this stain (for which the name 'neutral' red is misleading) can act as an indicator, red being the colour it adopts in acid media. Squashing of an excised piece of the mantle beneath a cover-glass causes the acid fluid to be released by rupture of some of the cells. The secretion at first takes the form of large spherules, one from each epidermal cell, but they soon merge and disperse through the surrounding medium.

Simple calcareous spicules are present in the subepidermal layer of the mantle. That these can exist in such close proximity to cells containing a strongly acid fluid is rather surprising; when a small piece of the mantle is compressed under a cover-glass the acid is freed and the spicules rapidly dissolve.

As in Pleurobranchus, cilia are not detectable in the mantle after fixation, and the metapodial gland, which develops late in life, is histologically complex and does not seem to be concerned with acid secretion.

\section{Philine quadripartita}

The whole integument is able to secrete the acid fluid. The epidermis differs markedly from that of the pleurobranchids; the acid glands are large, flask-shaped, subepidermal sacs, appearing as minute white specks in life and empty in sections. Between the sacs is a network of muscle fibres; discharge of the acid is probably brought about by the contraction of these fibres. Unicellular subepidermal mucous glands are also present, discharging to the exterior through separate ducts perforating the simple ciliated epidermis.

\section{Lamellaria perspicua and Velutina velutina}

As in Philine, the epidermis is simple and ciliated, while the acid glands take the form of subepidermal sacs communicating with the exterior by separate ducts perforating the epidermal layer. Muscle fibres are present around the sacs. The shell of Velutina is covered externally by a peculiar horny sheath; it seems probable that one of its functions is to protect the calcareous shell against the acid secretion of the animal's own foot. Fig. I illustrates diagrammatically the two types of epithelium found in acid-secreting gastropods.

\section{DISCUSSION}

All the gastropods described in this paper were found to be distasteful to fish; all are able to secrete a strongly acid fluid; all show similar glands in the skin. Strong circumstantial grounds exist for believing the glands to be in all cases the producers of the acid, and the acid to be the deterrent to the fish.

Bateson (1890) discovered that even dilute acids are repellent to a variety of fish. He states (p. 247): 'Conger are equally willing to eat a piece of squid or pilchard if it is covered or smeared with spirit, cheese of various sorts, 
anchovy extract, or Balanoglossus, as if it had been unpolluted. On the other hand, they will refuse cooked or tainted food and food which has been soaked for a few moments in dilute acids. The same remarks apply generally to the other fishes'. There can thus be little doubt that it was the acid secretion which brought about the rejection of the gastropods used in my experiments. This is further supported by the fact that dead or dying Berthella were eaten readily;
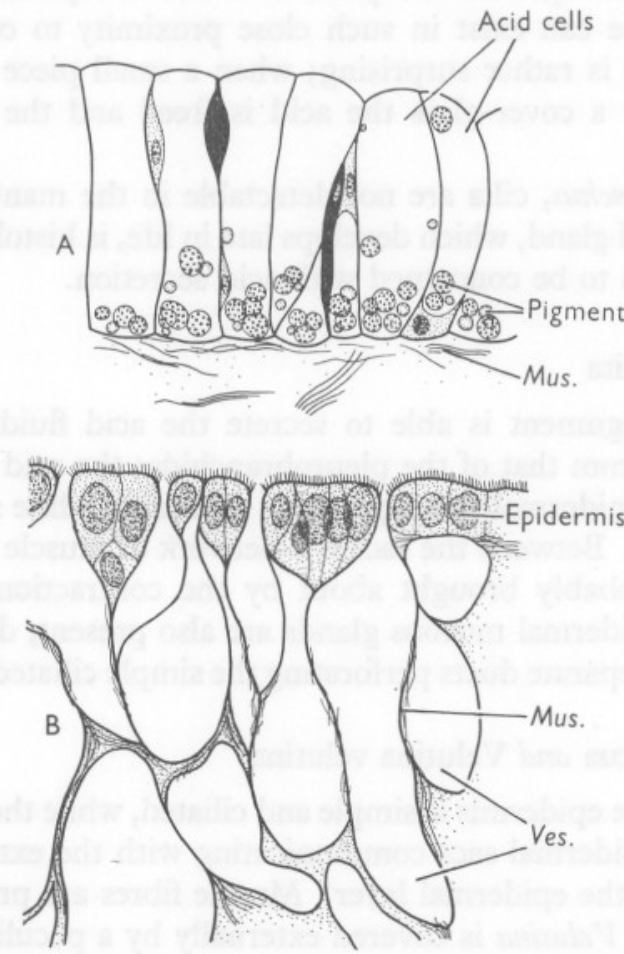

Fig. I. Diagrams of sections through the two types of acid-secreting epithelia found in gastropods. A, characteristic of Berthella plumula and Pleurobranchus membranaceus; B, characteristic of Philine quadripartita, Lamellaria perspicua and Velutina velutina. Mucous glands are shown black. Mus., muscle fibres. Ves., empty acid vesicles.

the deterrence is essentially a living process and cannot be explained simply on the grounds that the test foods were unfamiliar to the fish.

That the acid is produced by the glands described in this paper is difficult to prove, but is supported by much indirect evidence: (I) the histological structure of the median buccal gland (acid gland) of Pleurobranchus (Thompson \& Slinn, 1959) is remarkable for the 'empty' appearance of the cells in stained sections. Because these cells undoubtedly secrete acid, and because all the glands described in the present paper resemble them so closely, there are grounds for believing the function of all to be the same. (2) Excised pieces of 
the mantle skirt of Berthella can secrete acid; this rules out any possibility that the fluid might reach the exterior by seepage from the median buccal gland of the pleurobranchids. (3) Preparations of small excised pieces of the mantle of Berthella showed that rupture of the epidermal cells and liberation of the contained fluid (which neutral red staining showed to be acidic) was followed closely by the solution of the subepidermal calcareous spicules. This is proof of the acid-secreting function of the 'empty' epidermal cells of Berthella, and provides further grounds for believing, by analogy, the glands of the other species to have the same function.

Thus we may suppose that: $(a)$ large distinctive glands are present in the skin of the five species dealt with; (b) when the animal is disturbed acid is discharged by these glands; $(c)$ this acid secretion will usually cause the rejection of the mollusc by any fish which attempts to ingest it.

None of the five species is vividly coloured, notwithstanding Cooke's (I895) opinion that Pleurobranchus shows warning coloration. All, from Philine which lives submerged beneath sand or mud (Brown, 1934) to Lamellaria, which may bury itself in the ascidians on which it feeds (Herdman, 1893), are fairly effectively camouflaged. None shows any warning coloration or behaviour.

Acid secretion must have arisen independently in the Pleurobranchidae, the Philinidae and the Lamellariidae, which are distinct, well-defined taxonomic groups. This independent evolution of a similar defence mechanism in three groups of gastropods makes it all the more interesting that, while two of the groups (Philinidae and Lamellariidae) have evolved subepidermal acid glands (Fig. I B), the third (Pleurobranchidae) makes use of the epidermal cells for the purpose (Fig. IA). Perhaps the former condition was derived from an epithelium similar to that of modern pleurobranchids.

Although a considerable number of British gastropods have been tested during the present investigation, many more species undoubtedly would prove to have acid glands, if more naturalists were aware of the possibility of their existence. It is to be hoped that workers with the necessary skill will interest themselves in the chemical nature of these acid secretions; it would be of particular interest to know whether essentially the same acids are produced by the various groups. Furthermore, the functioning of the epidermal cilia in animals whose external $\mathrm{pH}$ may vary from I to 7 within a few seconds deserves further attention.

The author is indebted to $\mathrm{Mr} \mathrm{J}$. S. Colman for critical reading of the manuscript and for the provision of laboratory facilities. In addition it is a pleasure to acknowledge the assistance given by Mr R. G. Hartnoll, Mr D. Eggleston and $\mathrm{Mr}$ P. J. Miller in collecting the material on which this paper is based. The work was done while the author was holder of a Leverhulme Fellowship in the University of Liverpool. 


\section{SUMMARY}

The ability, on being abruptly disturbed, to secrete through the skin strongly acid fluids (approximately $\mathrm{pH} \mathrm{I}$ ) is recorded for five species of British gastropod molluscs. These are the prosobranchs Lamellaria perspicua and Velutina velutina and the opisthobranchs Philine quadripartita, Berthella plumula and Pleurobranchus membranaceus. All but Velutina lack an external shell as adults.

The tissue responsible for the acid secretions presents a characteristically 'empty' appearance in histological preparations. In Lamellaria, Velutina and Philine the acid glands take the form of subepidermal sacs communicating with the exterior through separate ducts perforating the simple ciliated epidermal layer. In Berthella and Pleurobranchus the secretion is elaborated within the ciliated epidermal cells themselves.

The ability to secrete acid fluids through the skin appears to have arisen independently at least three times, for the three families concerned in this study (Pleurobranchidae, Philinidae and Lamellariidae) are not closely related.

Tests in large aquaria led to the conclusion that the above-mentioned gastropods are invariably rejected as food by a variety of species of fish. After a consideration of the reliability of such tests, it is concluded that it is in fact the acid-secretion mechanism of the gastropod which is responsible for the deterrence of predatorial fish.

It is suggested that the ability to secrete acids through the skin may be a widespread phenomenon among gastropods.

\section{REFERENCES}

BAtESON, W., I890. The sense-organs and perceptions of fishes; with remarks on the supply of bait. F. mar. biol. Ass. U.K., Vol. I, pp. 225-56.

Brown, H. H., 1934. A study of a tectibranch gasteropod mollusc, Philine aperta (L.). Trans. roy. Soc. Edinb., Vol. 58, pp. 179-210.

Cooke, A. H., 1895. Molluscs in The Cambridge Natural History, Molluscs and Brachiopods, 535 pp. London: Macmillan.

CROSSLAND, C., I9II. Warning coloration in a nudibranch mollusc and in a chameleon. Proc. zool. Soc. Lond., Vol. 79, pp. 1062-7.

GarstanG, W., I890. A complete list of the opisthobranchiate Mollusca found at Plymouth. F. mar. biol. Ass. U.K., Vol. I, pp. 399-457.

Herdman, W. A., I893. 'Mimicry' of Lamellaria perspicua. Conchologist, Vol. 2, pp. 129-30.

HerdMAN, W. A. \& ClubB, J. A., I892. Third report on the Nudibranchiata of the L.M.B.C. district. Proc. Lpool Biol. Soc., Vol. 4, pp. I3I-69.

ROBERTSON, J. D., I949. Ionic regulation in some marine invertebrates. F. exp. Biol., Vol. 26, pp. 182-200.

STEEdMAN, H. F., 1950. Alcian blue 8GS: a new stain for mucin. Quart. F. micr. Sci., Vol. 91, pp. 477-9.

Thompson, T. E. \& SLInN, D. J., 1959. On the biology of the opisthobranch Pleurobranchus membranaceus. F. mar. biol. Ass. U.K., Vol. 38, pp. 507-24. 